In New Jersey at present, the night-time acciclent rates on three unlighted main roads carrying dense traffic are 270 per cent more than the day-time rates. Another striking figure is that more than half the 36,400 people killed by motor-cars in 1935 were injured during the hours of darkness, although the braffic volume was certainly not more than one third that during the day-time. It is concluded that it is not surprising that American engineers are alarmed when they see that New York State, for example, makes an annual expenditure of about twenty-two million dollars in getting rid of railway, street and highway crossings, and yet does little towards the illumination of roads at night. The total number of preventable accidents in 1934 due to railway crossings was 151 .

\section{Merseyside Fauna and Flora}

The Liverpool Naturalists' Field Club has recently issued volumes of Proceedings covering its activities for 1934 and 1935. This brings its number of annual Proceedings since its inception in 1860 to seventy-five, a noteworthy accomplishment, for they provide a valuable reference on the changing fauna and flora of the industrial north-west of England. The two latest volumes consist largely of the Ornithological Section report by Eric Hardy, who has built up within the Society the largest organized bird study group in the area. This includes bird-census counts over special areas, organized surveys of bird-calls at dawn and dusk, and statistics of migration and birdringing, nesting and rookery counts, etc. The Ornithological Section, states the Committee Report, is now organized independently of, but connected with, the general Field Club. The Proceedings also include Mr. W. A. Makinson's presidential addresses for the two years : "The Joys of a Nature Lover" and "Trees and their Service to Man". Reference is made to the discovery, in the Field Club library, of proof that the Society's first president and founder, the Rev. H. H. Higgins, visited the convent at Sinai and examined the famous "Codex Sinaiticus" previous to the examination by the collector Tischendorf. Having traced the journals of this Sinai visit, it is hoped to publish them.

\section{The Scripps Institution of Oceanography}

The August issue of the Collecting Net (11, No. 5) contains an article entitled "Biological Research at the Scripps Institution of Oceanography" by Dr. Claude E. ZoBell. It is announced that Dr. T. Wayland Vaughan is retiring from the University of California, his successor being Dr. Harald U. Sverdrup. During Dr. Vaughan's administration, the Scripps Institute of Oceanography has expanded enormously, and since his appointment as director in 1924 he has gradually developed an extensive research programme in biological oceanography with workers in all subjects connected with it. Among the many great improvements an important one is the growth of the library, which now contains more than 14,600 volumes, 1,100 charts and 30,000 pamphlets. Dr. Vaughan has contributed to the Institution his own personal collection of 1,800 volumes and 6,000 reprints of relevant literature besides numerous periodicals.

\section{Physics Research at Osaka University}

VoL. 3 of the "Collected Papers in Physics" from Osaka University consists of thirteen copies of papers which have appeared in the Report of Radio Research in Japan, the Proceedings of the Physico-Mathematical Society of Japan, the Japanese Journal of Physics and the Proceedings of the Institute of Radio Engineers of the United States, between June 1935 and March 1936. They cover subjects such as atomic bombardment, short-wave production, modulation of oscillators, polar molecules, electron diffraction, neutrons and protons and dynatrons. The volume extends to about 125 pages, and is produced by wiring together the separate copies of the papers, with a title page and table of contents, the size of the page being $19 \mathrm{~cm}$. by $26 \mathrm{~cm}$. The original covers of the papers are retained. This inexpensive method of issuing collected papers from periodicals with pages of the same size seems worthy of extension.

\section{Misunderstanding and Misprint}

A CoRrespondent has sent us a copy of a programme for 1936-37 of a science society of a university, which contains two amusing misprints. The title of a paper to be contributed by a member of the zoological department of the university was sent in as "Life History of the Ling Cod". The secretary appears not to have recognized "ling" as a food fish of the cod family, so he altered the word to "living". The printers put the finishing touch upon the title by changing the last word also, so that the title appears as "Life History of the Living God", which must surely represent the most ambitious subject of a paper by a zoologist ever announced.

\section{The Influenza Epidemic}

The Ministry of Health reports that during the week ending January 16 the number of deaths ascribed to influenza in the 122 great towns of England and Wales was 1,100 , as compared with 768 in the previous week. The number of notifications of pneumonia in England and Wales was 2,823 as against 2,338 in the previous week. A considerable increase of influenzal cases has occurred in most of the naval and military commands; but the epidemic appears to be declining in certain parts of the south. The age distribution of deaths is somewhat reassuring, as it is not the type usually met with in severe epidemics. According to Science Service bulletins, a wave of influenza is passing over the United States.

\section{Parkes Memorial Prize}

Major E. F. W. MackenzIE, R.A.M.C., has been awarded the Parkes Memorial Prize for 1936 for his investigations into the ammonia-chlorine process of water purification in the field, coupled with research carried out by him in connexion with food supplies in India. The Parkes Memorial Prize is awarded 